\title{
Sweet Potato and Cassava Can Modify Cholesterol Profile in Humans with Moderately Raised Serum Cholesterol Levels
}

\author{
Trinidad P. Trinidad*, Rosario S. Sagum, Aida C. Mallillin, Melissa S. Borlagdan, \\ Marco P. de Leon, Theressa F. Aviles \\ Food and Nutrition Research Institute, Department of Science and Technology, Taguig City, Philippines. \\ Email: *trinidadtp@yahoo.com.ph
}

Received June $25^{\text {th }}, 2012$; revised July $25^{\text {th }}, 2012$; accepted August $2^{\text {nd }}, 2012$

Copyright (C) 2013 Trinidad P. Trinidad et al. This is an open access article distributed under the Creative Commons Attribution License, which permits unrestricted use, distribution, and reproduction in any medium, provided the original work is properly cited.

\begin{abstract}
Sweet potato (kamote) and cassava are good sources of dietary fiber and resistant starch and are staple foods in the Philippines. The objective of the study is to determine changes in glucose and lipid profile after consumption of sweet potato and cassava in humans with moderately raised serum glucose and lipid profile. Sweet potato (Ipomoea batatas, Super Taiwan variety), and cassava (Manihot esculenta) were used as test foods while white bread was used as the control food. Fifty-nine apparently healthy human adults were fed with the test foods for 90 days and grouped into three: Control, Sweet potato and Cassava. After an overnight fast, $10 \mathrm{~mL}$ blood samples were taken from the study participants for total cholesterol, HDL-C, LDL-C, triglycerides, glucose and hemoglobin A1C measurements. Height/weight and percent fat mass were also determined. The groups given sweet potato and cassava significantly increased $\mathrm{HDL}-\mathrm{C}$ ( $\mathrm{P}<$ 0.05). There was a significant decrease in LDL-C in the cassava group $(\mathrm{P}<0.05)$. The group given slice bread significantly increased serum triglycerides $(\mathrm{P}<0.05)$. No significant results were observed with regards to BMI, percent fat, glucose, HbA1C, and total cholesterol. In conclusion, sweet potato and cassava increased HDL-C and decreased LDL-C in humans with moderately raised serum glucose and cholesterol levels. Sustainable intake of sweet potato and cassava may be promising in the prevention for risk of cardiovascular diseases as well as obesity and type 2 diabetes mellitus.
\end{abstract}

Keywords: Sweet Potato; Cassava; HDL-Cholesterol; LDL-Cholesterol

\section{Introduction}

The Philippines is one of the major producers of root crops in Asia along with Thailand, Indonesia, India, China and Vietnam. Root crops such as sweet potato (kamote) and cassava are used as staples of many people in the Philippines, e.g. Batanes, Cebu, Lanao, Zamboanga and Sulu. Root crops are good sources of dietary fiber $(5 \%-14 \%)$. Dietary fiber comes from the family of carbohydrates, a non-starch polysaccharide, not digested in the small intestine but may be fermented in the colon into short chain fatty acids (SCFA) such as acetate, propionate and butyrate. SCFA contributes $1.5-2.0 \mathrm{kcal} / \mathrm{g}$ dietary fiber [1]. The dietary fiber present in root crops is mostly galacto-mannans and other fermentable fibers [2-4].

Dietary fiber has been shown to have important health

*Corresponding author. implications in the prevention for risks of chronic diseases such as cardiovascular diseases and diabetes mellitus. Propionate, a product of dietary fiber fermentation in the colon, has been shown to inhibit the activity of the enzyme $\mathrm{HMG}$ CoA reductase, the limiting enzyme for cholesterol synthesis [5]. Dietary fiber has the ability to bind with bile acids and prevent its re-absorption in the liver thus, inhibit cholesterol synthesis. Dietary fiber's viscose and fibrous structure can control the release of glucose with time in the blood, thus help in the proper control and management of diabetes mellitus and obesity $[6,7]$.

The Philippines prevalence of chronic diseases accounted for $57 \%$ of all deaths in 2002, cardiovascular disease $-27 \%$, diabetes mellitus - $3 \%$, cancer $-9 \%$, and others-18\% (WHO, 2002). The Philippines has the $10^{\text {th }}$ highest incidence of diabetes worldwide. An estimated six million Filipinos know they have diabetes and an- 
other estimated six million who have diabetes but don't know they have it. Health experts believe many more have impaired glucose tolerance (IGT) and are prone to diabetes. Experts project that by 2030, this figure will be more than double.

The Food and Nutrition Research Institute-DOST had an acute (short term) study on the glycemic index and cholesterol-lowering effect of root crops [8]. All root crops were considered low glycemic index foods $(\mathrm{GI} \leq$ 55 ) and have shown to be potentially hypocholesterolimic foods [8]. These results showed potential health benefits of root crops in the prevention for risk of chronic diseases such as cardiovascular diseases and diabetes mellitus. However, there is a need for a longer term nutrition intervention study to validate the above results.

The utilization of root crops as a functional food will not only solve the problem of chronic diseases now prevailing in almost all countries but also encourage the industry and farmers to produce value-added or healthy products from root crops. This will increase the production and promotion of root crops.

The objective of the study is to determine the changes in blood serum glucose, hemoglobin $\mathrm{A} 1 \mathrm{C}$, and lipid profile of humans with moderately raised serum glucose and lipid profile after inclusion of root crops in their daily meals.

\section{Materials and Methods}

\subsection{Test Foods}

Sweet potato (Ipomoea batatas, Super Taiwan variety; maturity 100 - 120 days), and cassava (Manihot esculenta, golden yellow variety; maturity $100-120$ days) were used as test foods in the study. Sweet potato and cassava were supplied by root crops supplier from Divisoria Market as recommended by Phil Root crops (Visca, Baybay, Leyte). The control food was sliced white bread bought from a bakery shop. The serving size of all test foods was based on 50-gram available carbohydrates.

\subsection{Analytical Methods}

The data on proximate and dietary fiber composition of root crops used in the study was based on previous work [8]. Resistant starch was analyzed using AOAC method [9].

\subsection{Protocol of the Study}

Out of 115 humans screened, 59 apparently healthy adult human aged 35 - 60, non-smokers, no medications and with moderately raised blood glucose and lipid profile passed the criteria as study participants. They were grouped into three: Group I-Control (18; 16 females and 2 males); Group II-Kamote (20; 17 females and 3 males); and Group III-Cassava (21; 18 females and 3 males).

The study participants were made to fast overnight (10 12 hours of fasting) prior to the study. Ten $\mathrm{mL}$ blood samples were taken into plain glass tubes from the forearm vein, left to clot at room temperature, centrifuged, and the serum separated. Total cholesterol, HDL cholesterol and triglycerides were measured in a clinical chemistry analyzer (BS-120 Chemistry Analyzer, Shenzhen Mindray, Bio-medical Electronics Inc. Ltd., Shen Zhen, China) against standards (Cholesterol, Cholesterol Standard, $200 \mathrm{mg} / \mathrm{dL}$, Sentinel CH, Milan, Italy; HDL Cholesterol, Cholesterol Standard, $50 \mathrm{mg} / \mathrm{dL}$, Sentinel $\mathrm{CH}$, Milan, Italy; Triglycerides, Glycerol Standard, 200 $\mathrm{mg} \cdot \mathrm{dL}$, Sentinel $\mathrm{CH}$, Milan, Italy). The amount of LDL was estimated from the formula used by Wolever et al. [10] as follows:

$$
\mathrm{LDL}=(\text { total cholesterol }-\mathrm{HDL})-\text { triglyceride } / 2.2)
$$

Hemoglobin A1C (HbA1C) was sent to Hi-Precision Diagnostic Center for analysis. Anthropometric (height and weight) and body composition (Bio-impedance) meaurements were done at baseline and endline.

Study participants served as their own control. The participants were given the test foods to consume everyday to ensure compliance, except on Fridays when 3 test foods were given to include Saturday and Sunday intakes for 90 days.

The study participants signed voluntary consent forms approved by the Institutional Human Ethics Committee, Food and Nutrition Research Institute, Department of Science and Technology, Metro Manila, Philippines.

\section{Results}

Sweet potato (Kamote) has significantly higher resistant starch $(3.9 \pm 0.2 \mathrm{~g} / 100 \mathrm{~g}$ Sample) than that of cassava (3.5 $\pm 0.1 \mathrm{mg} / 100 \mathrm{~g}$ Sample; $\mathrm{P}<0.05)$. Similarly, previous study showed that the dietary fiber content of kamote $(8.1 \pm 0.1 \mathrm{~g} / 100 \mathrm{~g}$ Sample) was significantly higher than that of cassava $(4.6 \pm 0.2 \mathrm{~g} / 100 \mathrm{~g}$ Sample; $\mathrm{P}<0.05)$ [8].

Study participants were homogenous in terms of age and BMI shown not to be significantly different in all groups (Table 1).

No significant results between baseline and after consumption of the different test foods were observed with regards to BMI, percent fat, glucose, $\mathrm{HbA1C}$, and total cholesterol (Table 2). The control group given slice bread significantly increased their serum triglycerides but not with the group given kamote and cassava (Figure 1; Table 2; $\mathrm{P}<0.05$ ).

Also, there was a significant decrease in LDL-C in the 
Table 1. Characteristics of subjects, mean \pm SEM.

\begin{tabular}{cccc}
\hline Group & No. of Participants & AGE & BMI \\
\hline Control & $18=16$ Female +2 Male & $47.6 \pm 1.7$ & $26.3 \pm 1.4$ \\
Kamote & $20=17$ Female +3 Male & $49.1 \pm 2.0$ & $24.6 \pm 0.7$ \\
Cassava & $21=18$ Female +3 Male & $48.5 \pm 1.9$ & $25.0 \pm 0.8$ \\
\hline
\end{tabular}

Table 2. Changes in body composition, glucose and lipid profile after consumption of test foods, mean \pm SEM.

\begin{tabular}{|c|c|c|c|c|c|c|c|c|c|c|c|c|c|c|c|c|}
\hline \multirow{2}{*}{ Group } & \multicolumn{2}{|c|}{$\mathrm{BMI} \mathrm{kg} / \mathrm{m}^{2}$} & \multicolumn{2}{|c|}{ Fat, $\%$} & \multicolumn{2}{|c|}{ Glu, mmol/dL } & \multicolumn{2}{|c|}{$\mathrm{HbA} 1 \mathrm{C}, \%$} & \multicolumn{2}{|c|}{$\begin{array}{l}\text { Total-C, } \\
\text { mg/dL }\end{array}$} & \multicolumn{2}{|c|}{$\begin{array}{l}\text { LDL-C } \\
\mathrm{mg} / \mathrm{dL}\end{array}$} & \multicolumn{2}{|c|}{$\begin{array}{l}\text { HDL-C } \\
\mathrm{mg} / \mathrm{dL}\end{array}$} & \multicolumn{2}{|c|}{$\begin{array}{c}\text { Triglycerides } \\
\text { mg/dL }\end{array}$} \\
\hline & Base & End & Base & End & Base & End & Base & End & Base & End & Base & End & Base & End & Base & End \\
\hline Control & $\begin{array}{l}26.3 \\
\pm 1.4\end{array}$ & $\begin{array}{l}26.1 \\
\pm 1.3\end{array}$ & $\begin{array}{l}33.3 \\
\pm 1.5\end{array}$ & $\begin{array}{l}34.3 \\
\pm 1.3\end{array}$ & $\begin{array}{c}5.3 \\
\pm 0.5\end{array}$ & $\begin{array}{c}5.2 \\
\pm 0.4\end{array}$ & $\begin{array}{c}5.9 \\
\pm 0.4\end{array}$ & $\begin{array}{c}5.9 \\
\pm 0.3\end{array}$ & $\begin{array}{l}206.2 \\
\pm 1.0\end{array}$ & $\begin{array}{l}200.6 \\
\pm 5.4\end{array}$ & $\begin{array}{c}110 \\
\pm 4.4\end{array}$ & $\begin{array}{l}93.5 \\
\pm 7.1\end{array}$ & $\begin{array}{l}51.3 \\
\pm 2.9\end{array}$ & $\begin{array}{l}50.2 \\
\pm 2.6\end{array}$ & $\begin{array}{r}103.2 \\
\pm 10.9\end{array}$ & $\begin{array}{l}134.6^{*} \\
\pm 13.3\end{array}$ \\
\hline Kamote & $\begin{array}{l}24.6 \\
\pm 0.7\end{array}$ & $\begin{array}{l}24.3 \\
\pm 0.7\end{array}$ & $\begin{array}{l}32.4 \\
\pm 1.5\end{array}$ & $\begin{array}{l}32.8 \\
\pm 1.4\end{array}$ & $\begin{array}{c}5.0 \\
\pm 0.1\end{array}$ & $\begin{array}{c}4.8 \\
\pm 0.1\end{array}$ & $\begin{array}{c}5.6 \\
\pm 0.1\end{array}$ & $\begin{array}{c}5.6 \\
\pm 0.1\end{array}$ & $\begin{array}{l}232.9 \\
\pm 2.5\end{array}$ & $\begin{array}{l}235.6 \\
\pm 7.1\end{array}$ & $\begin{array}{l}126.6 \\
\pm 5.3\end{array}$ & $\begin{array}{l}118.0 \\
\pm 8.5\end{array}$ & $\begin{array}{l}50.6 \\
\pm 2.1\end{array}$ & $\begin{array}{l}61.2^{*} \\
\pm 6.6\end{array}$ & $\begin{array}{r}120.9 \\
\pm 12.6\end{array}$ & $\begin{array}{l}131.8 \\
\pm 12.1\end{array}$ \\
\hline Cassava & $\begin{array}{l}25.0 \\
\pm 0.8\end{array}$ & $\begin{array}{l}25.4 \\
\pm 0.8\end{array}$ & $\begin{array}{l}33.1 \\
\pm 1.3\end{array}$ & $\begin{array}{c}34.1 \\
\pm 0.8\end{array}$ & $\begin{array}{l}5.5 \\
\pm 0.5\end{array}$ & $\begin{array}{c}5.2 \\
\pm 0.4\end{array}$ & $\begin{array}{c}6.2 \\
\pm 0.5\end{array}$ & $\begin{array}{c}6.2 \\
\pm 0.5\end{array}$ & $\begin{array}{l}231.9 \\
\pm 3.6\end{array}$ & $\begin{array}{l}228.1 \\
\pm 6.2\end{array}$ & $\begin{array}{l}123.7 \\
\pm 5.2\end{array}$ & $\begin{array}{l}108.1^{*} \\
\pm 6.5\end{array}$ & $\begin{array}{l}51.8 \\
\pm 1.9\end{array}$ & $\begin{array}{l}62.2^{*} \\
\pm 4.5\end{array}$ & $\begin{array}{r}127.5 \\
\pm 12.9\end{array}$ & $\begin{array}{r}133.9 \\
\pm 12.5\end{array}$ \\
\hline
\end{tabular}

*Denote significant differences between baseline and endline at $\mathrm{P}<0.05$.

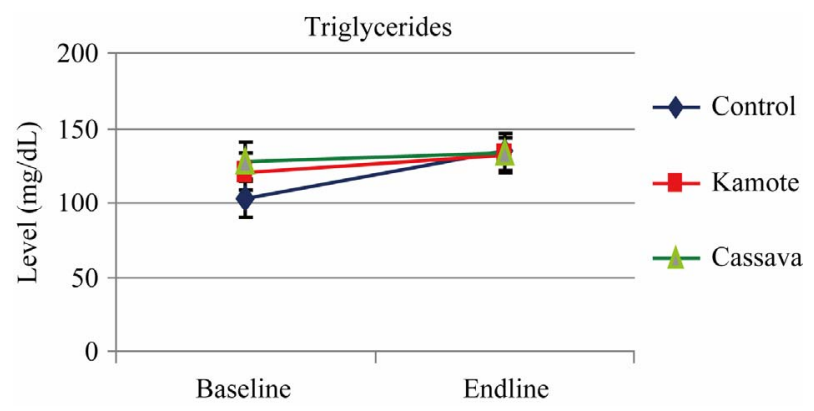

Figure 1. Changes in serum triglycerides after consumption of test foods. Humans given white bread significantly increased serum triglycerides $(P<0.05)$.

group given cassava but not with those given the bread and kamote although a decreasing trend was also observed (Figure 2; Table 2; $\mathrm{P}<0.05$ ). This result was similar to our previous acute study on the cholesterol lowering effect of both root crops (8). Significant increased in HDL-C was observed in groups given kamote and cassava (Figure 3; Table 2; $\mathrm{P}<0.05$ ).

\section{Discussion}

The hypocholesterolemic property of dietary fiber is associated with the water-soluble fractions of fiber which is fermentable in the colon, e.g. galactomannans, uronic acid, glucomannans, galacturonic acids. However, various water-soluble fibers may differ in their ability to reduce serum cholesterol [11-13]. Sweet potato (kamote) is a significant source of dietary fiber and is high in pectin content, 5 percent of the fresh weight or 20 percent of the dry matter at harvest [14] as well as galaturonic acid [15].

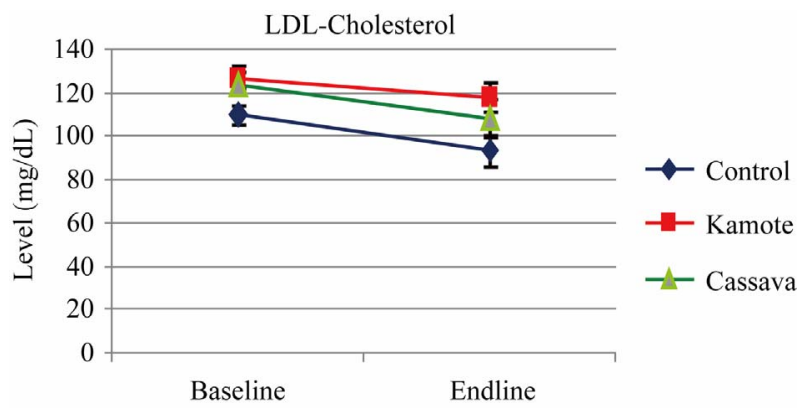

Figure 2. Changes in LDL-C after consumption of test foods. Humans fed with cassava significantly decrease their LDL$C$ from baseline to endline $(P<0.05)$.

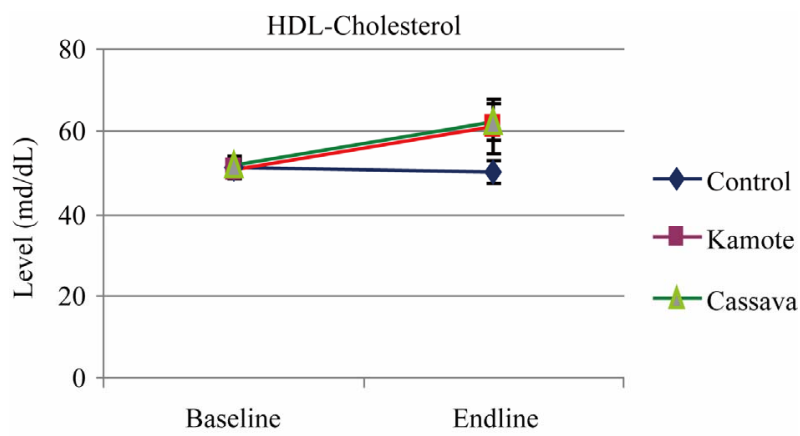

Figure 3. Changes in HDL-C after consumption of test foods. Humans fed with kamote and cassava significantly increased HDL-C from baseline to endline $(P<0.05)$.

As shown in this study, kamote has also significant amounts of resistant starch, shown to also be fermentable in the colon.

On the other hand, similar to kamote, cassava is also a 
good source of dietary fiber and detected to contain fucose (6-deoxy L-galactose) in its cell wall materials [15] and has already been shown to lower LDL-C in a previous acute study on root crops [8] and was validated in the present study.

The significant increase in HDL cholesterol levels of all study participants after consumption of kamote and cassava observed in this study was a good result as most Filipinos were found to have a very low HDL-C according to the recent 2008 FNRI National Nutrition Survey. The concentration of serum HDL cholesterol is affected by alcohol intake and body mass index (BMI) [16]. However, all study participants do not drink alcohol and the BMIs were not significantly different between study participants in the duration of the experimental period.

Although both root crops studied did not lower serum total cholesterol in the duration of the study ( 90 days), the quality of the cholesterol in terms of "good" and "bad" were changed. The LDL-C (bad) was decreased while the HDL-C (good) was increased.

\section{Conclusion}

Sweet potato (kamote) and cassava did not lower serum total cholesterol in the duration of the study however, modified the cholesterol composition, increased HDLcholesterol and decreased LDL-cholesterol. The sustainable intake of root crops such as sweet potato or "kamote" and cassava may not only modify serum cholesterol composition but may lower total cholesterol levels, and may play a significant role in the prevention for risk of cardiovascular diseases as well as obesity and type 2 diabetes mellitus.

\section{Acknowledgements}

The authors are grateful to Ms. Teresa S. Mendoza, Project Coordinator of "Combating Double Burden Malnutrition Through Industry Driven R \& D Programs" where this study is a part of the program, to Fei Amster P. Baquiran, Kristine Bernadette B. Cid, James David S. Alcantara, Zoilo B. Villanueva, Mark Ryan Q. Ibardaloza, and Michael J. Guevarra for their technical assistance; and to the Philippine Council for Industry, Energy and Emerging Technology Research and Development for funding the study.

\section{REFERENCES}

[1] M. Roberfroid, "Health Benefits of Non-Digestible Oligosacchaides," In: D. Kritchevsky and C. Bonfield, Eds., Dietary Fiber in Health and Disease. Advances in EXperimental Biology, Plenum Press, New York and London, 1997, Vol. 4.

[2] M. Champ, J. M. Brillouet and X. Rouau, "Non-Starchy
Polyssacharide of Phaseolus Vulgaris, Lens Esculenta and Cicer Arietinum Seeds," Journal of Agriculture and Food Chemistry, Vol. 34, No. 2, 1983, pp. 326-329. doi:10.1021/jf00068a044

[3] W. D. Holloway, J. A. Monro, J. C. Gurnsey, E. W. Pomare and N. H. Stace, "Dietary Fiber and Other Constituents of Some Tongan Foods," Journal of Food Science, Vol. 50, No. 6, 1985, pp. 1756-1757. doi:10.1111/j.1365-2621.1985.tb10586.x

[4] N. C. Howarth, E. Saltzman, M. A. McCrory, A. S. Greenberg, J. Dwyer, L. Ausman, D. G. Kramer and S. B. Roberts, "Fermentable and Non-Fermentable Fiber Supplements Did Not Alter Hunger, Satiety or Body Weight in a Pilot Study of Men and Women Consuming Self-Selected Diets," Journal of Nutrition, Vol. 133, No. 10, 2003, pp. 3141-3144.

[5] W. J. L. Chen, J. W. Anderson and D. J. A. Jenkinds, "Propionate May Mediate the Phypocholesterolemic Effects of Certain Soluble Plant Fibers in Cholesterol-Fed rats," Proceedings of the Society for Experimental Biology and Medicine, Vol. 175, No. 2, 1984, pp. 215-218.

[6] D. J. A. Jenkins, A. Ghafari, T. M. S. Wolever, R. H. Taylor, H. M. Barker, H. Filden and A. L. Jenkins, "Bowling Ac. Relationship between the Rate of Digestion of Foods and Post-Prandial Glycemia," Diabetologia, 1982, Vol. 22, No, 6, pp. 450-455. doi:10.1007/BF00282589

[7] W. Creutzfeldt and R. U. Folsch, "Delaying Absorption as a Therapeutic Principle in Metabolic Diseases," Thiem-Stratton, New York, 1983, p. 1.

[8] T. P. Trinidad, A. C. Mallillin, A. C. Loyola, R. R. Encabo and R. S. Sagum, "Nutritional and Health Benefits of Root Crops," In: Bioactivity Foods in Promoting Health: Fruits and Vegetables, Academic Press, Oxford, 2009, pp. 717-728.

[9] Association of Analytical Chemists (AOAC) "Method 2002.02 Resistant Starch Assay Procedure,” 2002.

[10] T. M. S. Wolever, D. J. A. Jenkins and S. Mueller, "Method of Administration Influences the Serum-Cholesterol Lowering Effect of Psyllium," American Journal of Clinical Nutrition, Vol. 59, No. 5, 1994, pp. 1055-1059.

[11] R. W. Kirby, J. W. Anderson, B. Sieling, E. D. Rees, D. J. L. Chen, R. E. Miller and R. M. Kay, "Oat Bran Intake Selectively Lowers Serum LDL Cholesterol Concentration of Hypercholesterolimic Men," American Journal of Clinical Nutrition, Vol. 34, No. 5, 1981, pp. 824-829.

[12] D. J. A. Jenkins, A. R. Leeds, C. Newton and J. H. Cummings, "Effect of Pectin, Guargum and Wheat Fiber on Serum Cholesterol," Lancet, Vol. 305, No. 7916, 1975, pp. 1116-1117. doi:10.1016/S0140-6736(75)92503-9

[13] L. P. Bell, K. J. Hectorn, H. Reynolds and D. B. Hunninghake, "Cholesterol-Lowering Effects of Soluble Fiber Cereals as Part of a Prudent Diet for patIents with Mild to Moderate Hypercholesterolemia," American Journal of Clinical Nutrition, Vol. 52, No. 6, 1990, pp. 1020-1026.

[14] W. W. Collins and W. M. Walter Jr., "Potential for Increasing the Nutritional Value of Sweet Potatoes," In: R. 
L. Villareal and T. F. Griggs, Eds., Sweet Potatoes. Proceedings of the First International Symposium, 1982, Hon Wen Printing, Woks, Tainan, pp. 355-363.

[15] L. D. Salvador, T. Suganuma, K. Kitahara, H. Tanoue and M. Ichiki, "Monosaccharide Composition of Sweet Potato Fiber and Cell Wall Polysaccharides from Sweet Potato, Cassava and Potato Analyzed by the High-Performance Anion Exchange Chromatography with Pulsed Amperometric Detection Method," Journal of Agricultural and Food Chemistry, Vol. 48, No. 8, 2000, pp. 3448-3454. doi:10.1021/jf991089z

[16] C. Bolton-Smith, M. Woodward, W. C. S. Smith and H. Tunstall-Pedoe, "Dietary and Non-Dietary Predictors of Serum Total and HDL-Cholesterol in Men and Women: Results from the Scottish Heart Health Study," International Journal of Epidemiology, Vol. 20, No. 1, 1991, pp. 95-104. doi:10.1093/ije/20.1.95 